\title{
MORPHOLOGY AND ANATOMY OF THREE SPECIES OF ASPLENIUM L. AT OBAFEMI AWOLOWO UNIVERSITY ILE-IFE, NIGERIA
}

\author{
Oladipo, O. T. ${ }^{1}$, Philip, T. V. ${ }^{1}$, Bamigboye, R. A. ${ }^{2}$ and Oloyede, F. A. ${ }^{1}$ \\ ${ }^{1}$ Department of Botany, Obafemi Awolowo University, Ile-Ife, Nigeria. \\ ${ }^{2}$ Natural History Museum, Obafemi Awolowo University, Ile-Ife, Nigeria. \\ Corresponding author's e-mail address: bamigboyeadebola@yahoo.com \\ (Received: $5^{\text {th }}$ August, 2019; Accepted: $28^{\text {th }}$ December, 2019)
}

\section{ABSTRACT}

Comparative morphological and foliar anatomical studies were carried out on three species of Asplenium: Asplenium nidus L., Asplenium scolopendrium (L.) Newn and Asplenium barterii Hook with a view to identifying important morphological and anatomical characters that can be employed in the separation of the species. Mature healthy plants of each species were collected from Erin Ijesa Waterfall and nursed in the Fern Garden of Natural History Museum at Obafemi Awolowo University, Ile-Ife. Morphological observations and measurements were documented for each species. The transverse sections of the petiole and stem foliar sections were prepared by cutting at $10 \mu \mathrm{m}$ thickness using Reichert Sliding Microtome and microphotographs were taken. Quantitative data obtained from this study were subjected to one-way Analysis of Variance with Duncan Multiple Range Test for mean separation. Findings revealed that the predominantly irregular epidermal cells on the adaxial surface of $A$. barterii is diagnostic of the species. The presence of tetracytic stomata in addition to anisocytic type also separates $A$. nidus from the other taxa. Similarly, $A$. scolopendrium had a significantly higher guard cell area compared to the other taxa. Morphological and foliar anatomical features in the genus can be used to delimit the three species while the possession of two vascular bundles broadly admit the species into the genus Asplenium.

Keywords: Asplenium, Taxonomic, Foliar anatomy, Morphology.

\section{INTRODUCTION}

The genus Asplenium belongs to the family Aspleniaceae. It is one of the most species-rich and widespread fern genus which contains about 700 species (Schneider et al., 2004). The species are well distributed in temperate and tropical regions of all the continents except Antartica (Yanfen et al., 2013). They grow epiphytically or terrestrially on damp shaded crevices and some species, for example Asplenium trichomanes, grow mainly on lime substrates (Brownsey and Perrie (2018). Asplenium species like most ferns are used as ornamentals. The medicinal uses of some species in the treatment of jaundice, high cough, cold, abscess of the uterus have also been reported (Mannan et al, 2008).

The affinities of members of Aspleniaceae are not stable. Although the family is well defined, the generic segregates have been reported to be problematic. Most of the generic and subgeneric divisions of the family are not satisfactory due to the occurrence of intermediate forms as a result of hybridization among the segregates (Crouch et al., 2011). Molecular phylogeny lumped majority of previously established genera in the family into a single genus Asplenium and 5-13 small satellite genera (Martins, 2014).

Ferns and Lycophytes are poorly studied in Nigeria and are gradually going into extinction. For example, the herbaria records of over 50 years ago reported about 25 species in southwestern Nigeria, while only six species were found on the field in a survey (Oloyede and Odu, 2011). Among the few existing species are the members of the genus Asplenium. Few taxonomic researches on ferns that have been reported in Nigeria include those of Bassey (1994) on the taxonomy of Adiantaceae; Oloyede and Odu (2011) on the taxonomic evaluation of Leptosporangiate ferns in southwestern Nigeria; Fajuke (2014) and Bamigboye (2018) on the biosystematics studies of genera Nephrolepis Schott and Pteris L. respectively.

There is no previous report on anatomical study of genus Asplenium and very little information is available on their morphology in Nigeria (Oloyede 
and Odu, 2011). This study is therefore designed to identify and document the morphological and anatomical features that are of diagnostic values in delimiting the three available species of Asplenium thereby enhancing the taxonomy of the genus in southwestern Nigeria.

\section{MATERIALS AND METHODS}

Three species of Asplenium: Asplenium nidus L., Asplenium scolopendrium L. Newn and Asplenium barterii Hook collected from Erin Ijesa waterfall (latitude $\mathrm{N} 07^{\circ} 3350.2$ and longitude $\left.004^{\circ} 5419.5\right)$ Osun state of Nigeria and nursed at the Museum Fern Garden were used for this study.

\section{Morphological Studies}

A study of qualitative and quantitative morphological characters were carried out on each of the species. Qualitative study was done by observing morphological features such as leaf apex, leaf margin, indusium, stipe colour, rhizome and sori on ten fronds per species. Features were observed and recorded. Quantitative characters studied were frond length $(\mathrm{cm})$, frond breadth $(\mathrm{cm})$, leaflet length $(\mathrm{cm})$ and leaflet breadth $(\mathrm{cm})$. This was done using meter rule to measure the parameters on stands of each of the species.

\section{Epidermal Studies}

The peeling of the epidermis for both the adaxial and abaxial surfaces was done by placing the leaflet of each species in a Petri-dish containing small amount of $100 \%$ concentrated nitric acid (HNO3) under the sun. After five minutes, the epidermal surfaces were teased off using forceps, rinsed thoroughly in water and stored in labelled vials containing $50 \%$ ethanol. The peels were later stained with Safranin $O$ for five minutes and rinsed in water to remove excess stain. The stained leaflets were mounted on slides with two to three drops of $25 \%$ glycerol. Anatomical features examined include, the nature of the epidermal cells, anticlinal wall patterns, stomata types, guard cells, crystal type and subsidiary cells. The guard cells and epidermal cells were measured with the use of a micrometer at $\mathrm{x} 40$ magnification. The guard cell areas were calculated by multiplying the length and breadth of 50 guard cells per species on the abaxial surface (since the leaves of the plants are hypostomatic). The formula used to calculate the guard cell area is:

Guard cell area $=$ Length $\times$ Breadth $\times \mathrm{K}$

Where K (Franco's constant $)=0.78524$ (Franco, 1939)

The stomata index (I) was also calculated using the formula:

$\mathrm{I}=\frac{S}{(E+S)} \times 100$

Where $\mathrm{S}=$ Number of stomata per unit area

$\mathrm{E}=$ Number of epidermal cells in the same unit area

The counting of stomata and epidermal cell was done with the use of a square micrometer.

\section{Transverse Section of the Leaflets and Stipes.}

Transverse sections of the leaflets and stipes were cut with the use of Reichert sliding microtome at $10 \mu \mathrm{m}$ thickness and preserved in 50\% ethanol until further studies. The specimens were later stained with Safranin O for five minutes, rinsed with water to remove excess stain, counter stained in Alcian blue for five minutes and again rinsed thoroughly in water to remove excess stain. The stained sections were then treated in 50\% and 70\% ethanol for dehydration and differentiation. After this, the sections were mounted on slides with $25 \%$ glycerol containing thymol (to prevent growth of moulds). The features examined on the sections include: outline of the stipes, epidermal cells, trichomes, mesophyll cells, vascular bundle type and shape.

\section{Venation Studies}

The leaflets of each of the species were boiled separately in a beaker containing $100 \%$ ethanol for 30 minutes to remove the chlorophyll pigment. Leaflets were afterwards rinsed with water about two to three times to remove traces of ethanol and were soaked in a beaker containing 5\% sodium hydroxide $(\mathrm{NaOH})$ solution for 10 minutes to further remove the chlorophyll pigment. The leaflets were then rinsed with water several times and placed in a beaker containing 5\% sodium hypochlorite for 30 minutes till the leaflets were completely cleared of chlorophyll. The cleared leaves were then rinsed in water thoroughly and stored in $50 \%$ ethanol. To view the cleared leaflets 
under microscope, the leaflets were stained with Safranin $O$ for five minutes and the excess stain was rinsed off with water. Stained leaflets were mounted on slides with two to three drops of $25 \%$ glycerol for microscopic examination. Photomicrograhs were taken with the aid of 3013 Accu-Scope trinocular microscope with digital camera.

\section{Statistical Analysis}

Quantitative data derived from various measurements were separately subjected to One
Way Anova while means were separated using Duncan Multiple Range Test from System Analysis Software, version 9.1. SAS Institute..

\section{RESULTS}

Both $A$. nidus and $A$. scolopendrium have simple fronds, while $A$. barterii has unipinnate fronds (Figure 1). Fronds of $A$. nidus are glabrous with less prominent stipes while A. scolopendrium fronds are wrinkled in texture with distinct stipes. Tables 1 and 2 show the summary of qualitative and quantitative morphological characteristics of
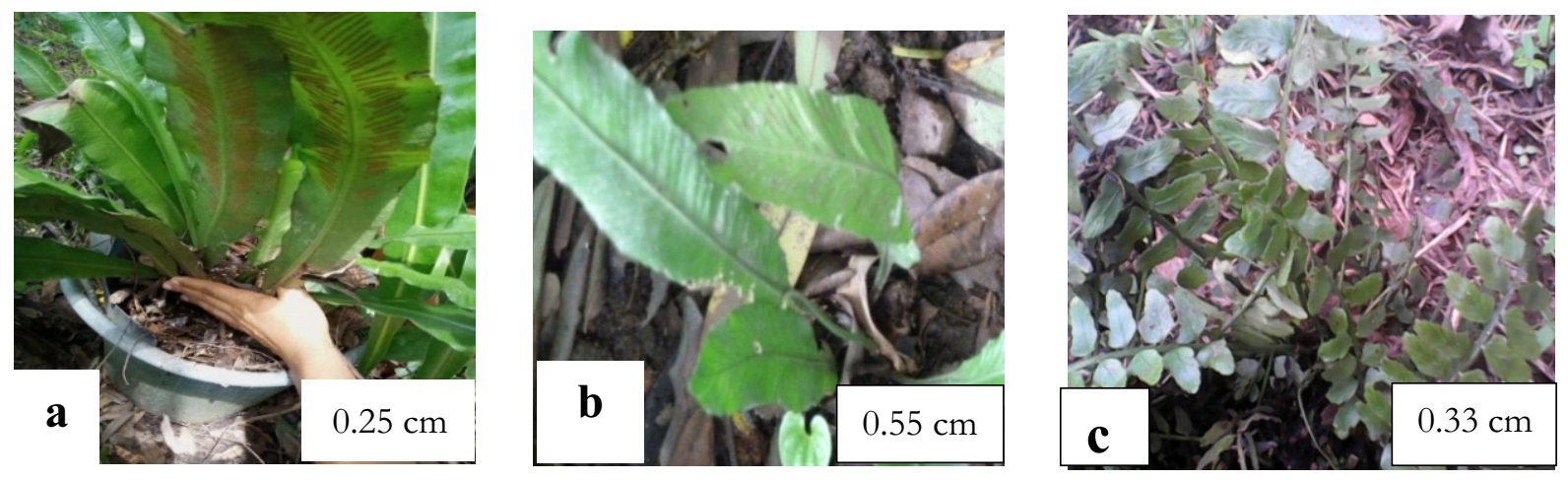

Figure 1 (a-c): Habits of the Asplenium species. (a) A. nidus (b) A. scolopendrium (c) A. barterii.

Table 1: Qualitative Morphological attributes of the Asplenium species

\begin{tabular}{|c|c|c|c|c|c|c|c|}
\hline \multirow[b]{2}{*}{ Species } & \multicolumn{7}{|c|}{ Character } \\
\hline & $\begin{array}{l}\text { Leaf } \\
\text { Apex }\end{array}$ & $\begin{array}{l}\text { Leaf } \\
\text { Margin }\end{array}$ & Frond & Indusium & $\begin{array}{l}\text { Stipe } \\
\text { Colour }\end{array}$ & Rhizome & Sori \\
\hline A. nidus & Acute & Entire & Simple & Present & Green & Erect & Elongated \\
\hline A. scolopendrium & Acute & Crenated & Simple & Present & $\begin{array}{l}\text { Green } \\
\text { adaxial } \\
\text { dark } \\
\text { Abaxial }\end{array}$ & Erect & Elongated \\
\hline A. barterii & Acuminate & Crenated & Pinnate & Present & $\begin{array}{l}\text { Green } \\
\text { with } \\
\text { dark } \\
\text { base }\end{array}$ & Erect & Elongated \\
\hline
\end{tabular}

Table 2: Quantitative Morphological Attributes of the Asplenium Species.

\begin{tabular}{lclll}
\hline \multicolumn{1}{c}{ Plant species } & Fl. $(\mathbf{c m})$ & Fb. $(\mathbf{c m})$ & Ll. $(\mathbf{c m})$ & Lb $(\mathbf{c m})$ \\
\hline A. nidus & $45.10 \pm 1.17$ & $6.10 \pm 0.42$ & - & - \\
A. scolopendrium & $16.00 \pm 1.14$ & $7.22 \pm 0.17$ & - & - \\
A. barterii & $14.20 \pm 1.16$ & $4.80 \pm 0.11$ & $2.10 \pm 0.09$ & $1.20 \pm 0.16$ \\
\hline
\end{tabular}

Abbreviations:

FL- Frond length, Fb- Frond breadth, Ll- Leaflet length, Lb- Leaflet breadth 
The photomicrographs of anatomical features of the Asplenium species are presented in figures 24. The summary of qualitative anatomical characters of the three species is presented in table 3 , while the mean values of important anatomical features are reported in tables $4 \mathrm{a}$ and $\mathrm{b}$. Epidermal cells in all the three species are generally polygonal to irregular on both surfaces while anticlinal walls patterns are undulating to wavy. The leaves of the three species are hypostomatic because stomata were observed only on their abaxial surfaces. The stomata shape observed were generally elliptic while the stomata types are anisocytic and tetracytic. On the transverse section of the leaflets and stipes, Epidermis is uniseriate in all the species. The mesophyll cells are not distinguished into palisade and spongy layers in $A$. nidus and $A$. barterii but they are distinguished in $A$. scolopendrium. Possession of two vascular bundles in the stipe and free venation pattern is common to all the three Asplenium species studied.

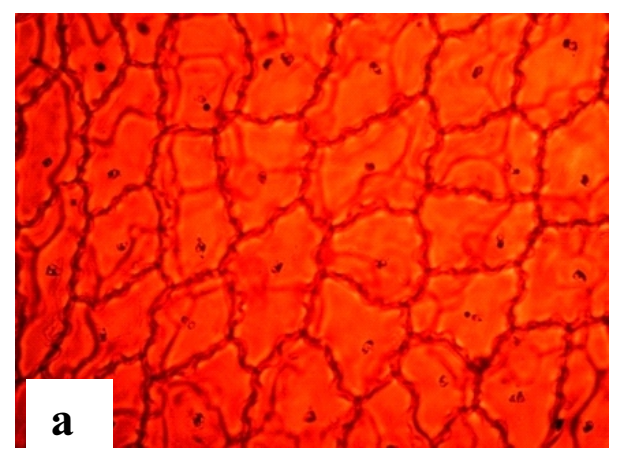

Mag. $\times 400$

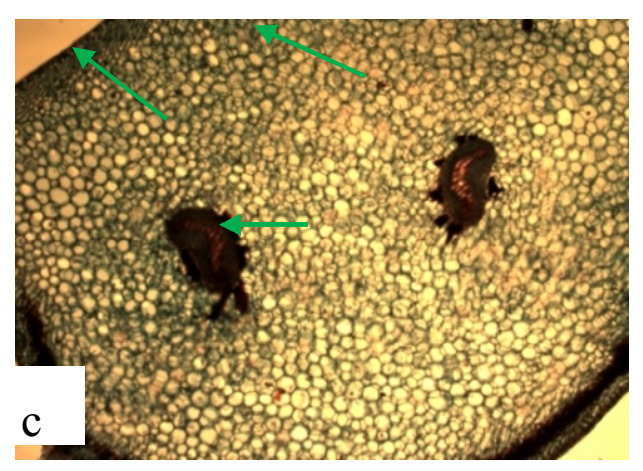

Mag. $\times 100$

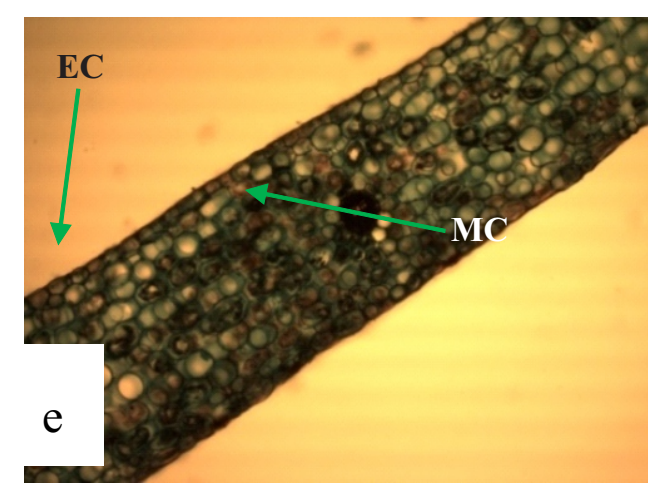

Mag. $\times 100$

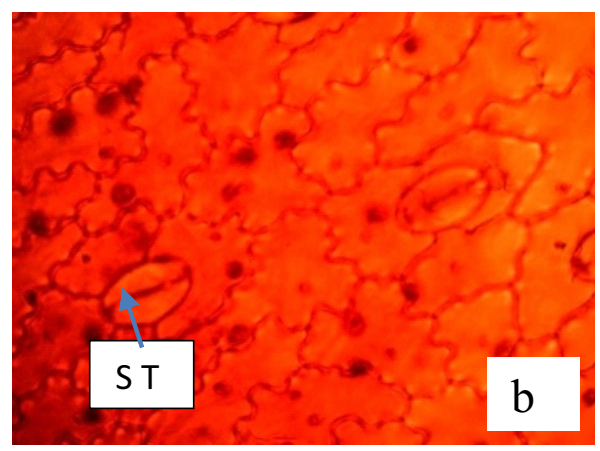

Mag. $\times 400$

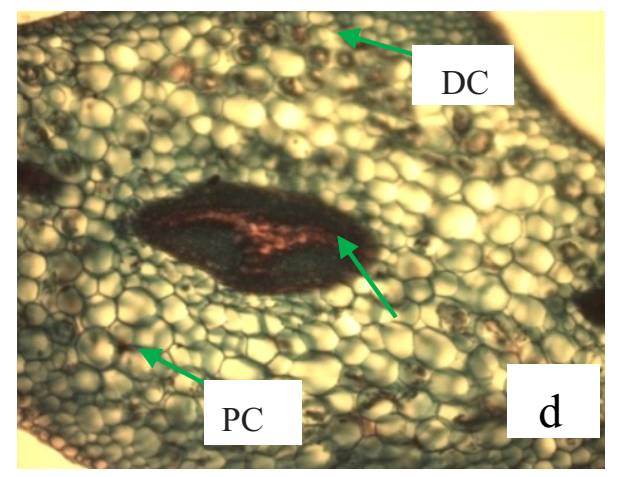

Mag. $\times 100$

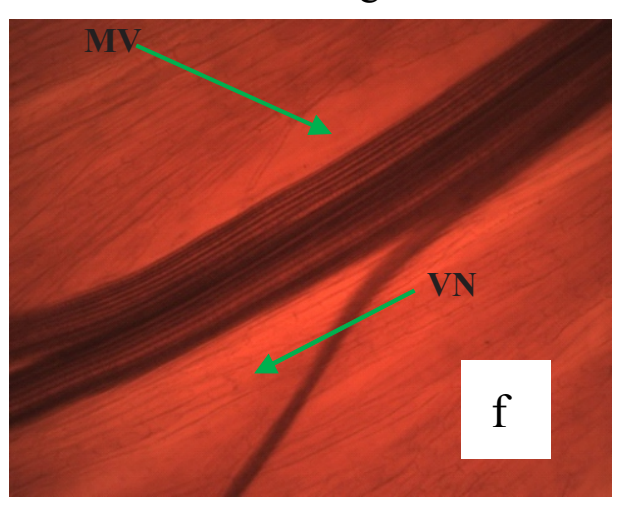

Mag. $\times 100$
Figure 2:

Anatomical Features of Asplenium nidus.

(a) Adaxial surface (b) Abaxial surface

(c) Transverse section of stipe (d) Transverse section of stipe (e) Transverse section of leaflet (f) Venation pattern

Abbreviations: SE- stele, SC, sclerenchyma, PC- parenchyma cell, MC-

mesophyll cells, PF- pericyclic fibre, MV- midvein, VN- vein, EC- epidermal cell, AWanticlinal wall, DC-druse crystal, STstomata, SCsubsidiary cell, Mag. -

Magnification 
Oladipo et al.: Morphology and Anatomy of Three Species of Asplenium L.

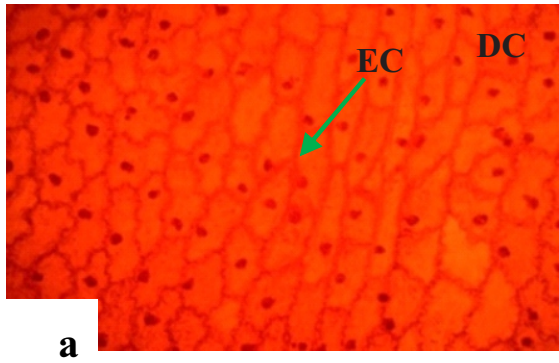

Mag. $\times 400$

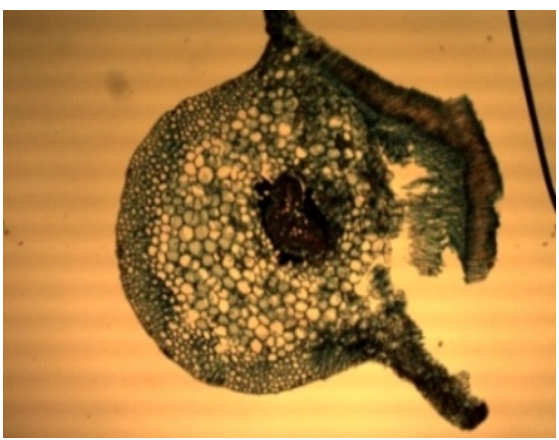

c Mag. $\times 100$

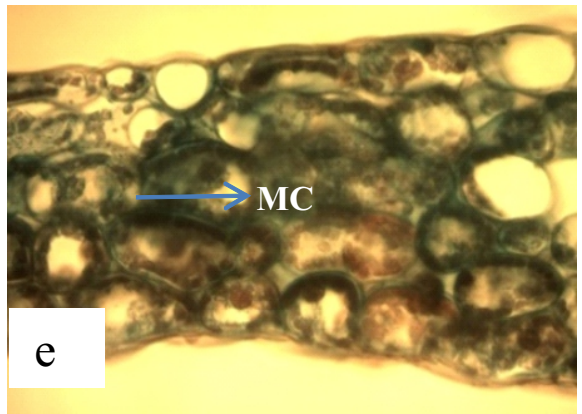

Mag. x 400

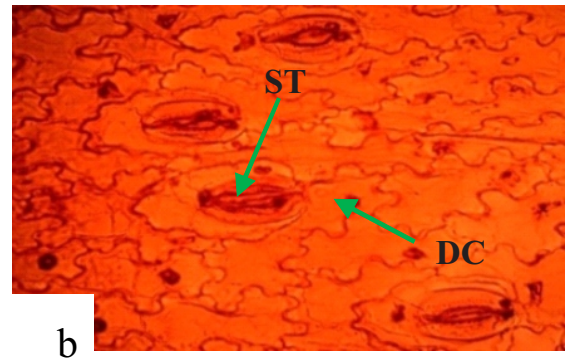

Mag. $\times 400$

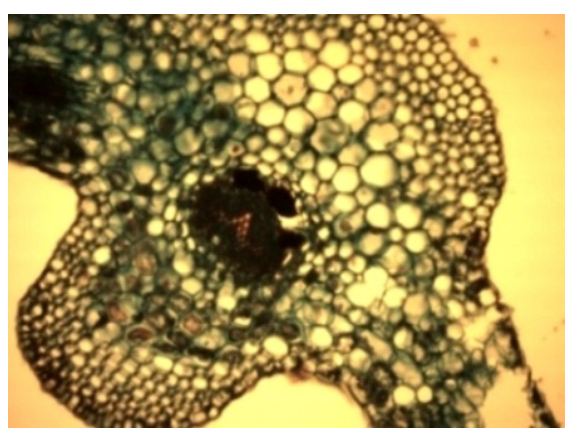

d Mag. $\times 400$

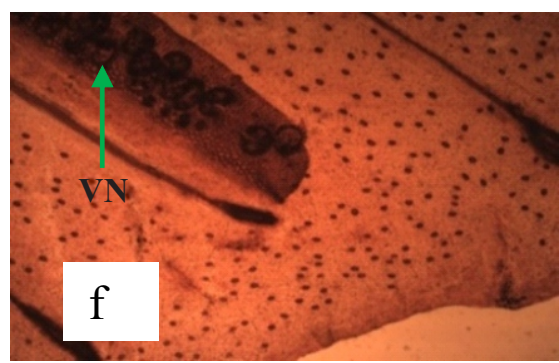

Mag. x 100

Figure 3: Anatomical Features of $A$. scolopendrium

(a) Adaxial surface (b) Abaxial surface (c) Transverse section of stipe (d) Transverse section of stipe (e) Transverse section of leaflet (f): Venation pattern.

Abbreviations: SR- sori, SE-stele, MC- mesophyll cell, PC- parenchyma cell, VN- vein, RB- rib, STstomata, EC- epidermal cell, DC- druse crystal, Mag. - Magnification. 


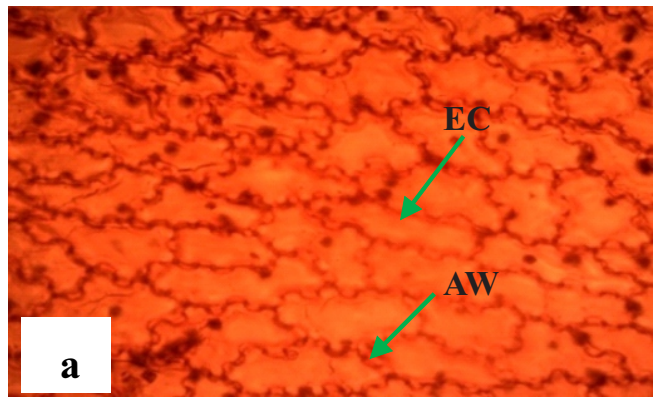

Mag. $\times 400$

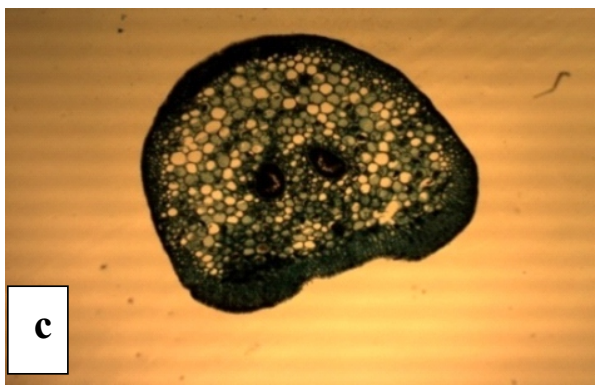

Mag. $\times 100$

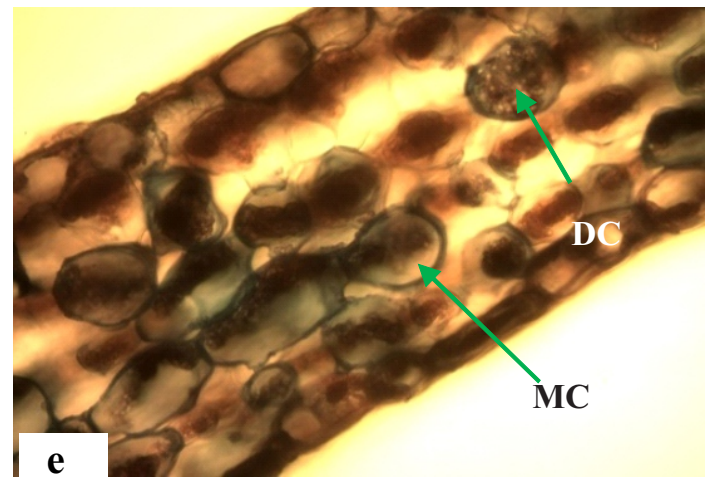

Mag. $\times 400$

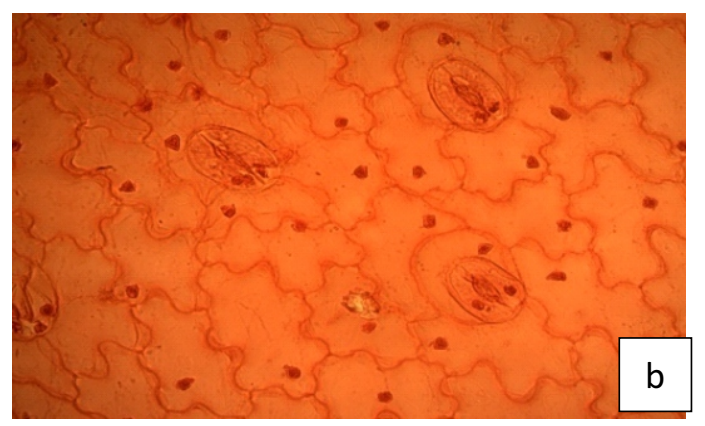

Mag. $\times 400$

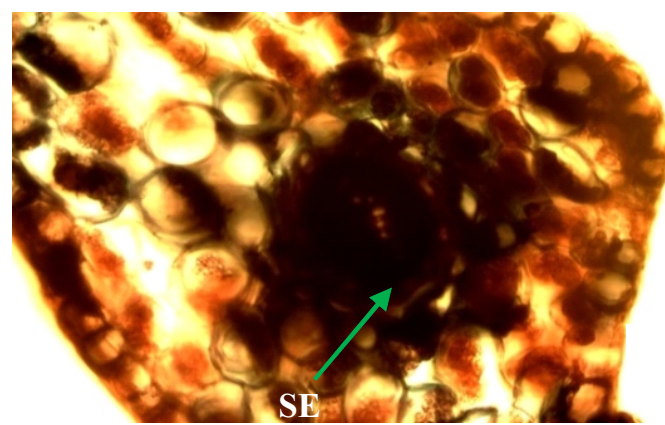

Mag. $\times 400$

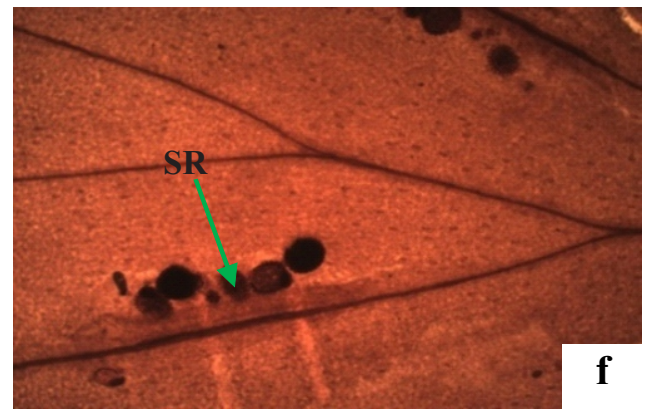

Mag. $\times 100$

Figure 4: Anatomical Features of Asplenium barterii

(a) Adaxial surface (b) Abaxial surface (c) Transverse section of stipe of $A$. barterii. (d) Transverse section of the stipe (e) Transverse section of leaflet (f) Venation pattern.

Abbreviations: SE- stele, EC- epidermal cells, SR- sori, MC- mesophyll cell, AW- anticlinal wall, SCsubsidiary cell, ST- stomata, DC- druse crystal, Mag. - Magnification. 
Table 3: Foliar Epidermal Characters of Three Asplenium Species.

\begin{tabular}{llll}
\hline Features & A. nidus & A scolopendrium & A. barterii \\
\hline
\end{tabular}

\section{Adaxial}

Epidermal cells Anticlinal walls

Stomata

Cell inclusions
Polygonal to irregular

Undulating

Absent

Druse crystals
Polygonal to irregular

Undulating

Absent

Druse crystals
Irregular

Undulat ing

Absent

Druse crystals

\section{Abaxial}

Epidermal cells

Anticlinal walls

Irregular

Wavy

Stomata

Anisocytic

Tetracytic

Cell inclusions

Druse crystals

Irregular

Undulating

Anisocytic

Druse crystals
Irregular

Undulating

Anisocytic

Table 4a: Mean Values of Important Quantitative Abaxial Epidermal Features of the Asplenium Species.

\begin{tabular}{|c|c|c|c|c|c|c|c|c|}
\hline Species & $\begin{array}{r}\text { Sn } \\
\text { AB }\end{array}$ & $\begin{array}{l}\text { Nec } \\
\text { AB }\end{array}$ & $\begin{array}{c}\text { Si } \\
\text { AB (\%) }\end{array}$ & $\begin{array}{c}\text { Gcl } \\
\mathrm{AB}(\mu \mathrm{m})\end{array}$ & $\begin{array}{c}\text { Gcw } \\
\mathrm{AB}(\boldsymbol{\mu m})\end{array}$ & $\begin{array}{c}\text { Gca } \\
\mathrm{AB}\left(\boldsymbol{\mu m}^{2}\right)\end{array}$ & $\begin{array}{c}\text { Ecl } \\
(\mathrm{AB} \mu \mathrm{m})\end{array}$ & $\begin{array}{c}\text { Ecw } \\
(\mathrm{AB} \mu \mathrm{m})\end{array}$ \\
\hline A. nidus & $2.04^{\mathrm{ab}}$ & $22.96^{b}$ & $8.17^{a}$ & $56.40^{b}$ & $39.80^{\mathrm{ab}}$ & $1822.54^{\mathrm{b}}$ & $130.10^{\mathrm{a}}$ & $65.4^{\mathrm{b}}$ \\
\hline A. scolopendrium & $1.80^{\mathrm{b}}$ & $24.08^{a b}$ & $7.10^{\mathrm{a}}$ & $65.50^{\mathrm{a}}$ & $41.80^{\mathrm{a}}$ & $2160.38^{\mathrm{a}}$ & $53.80^{\mathrm{b}}$ & $149.90^{\mathrm{a}}$ \\
\hline A. barterii & $2.40^{\mathrm{a}}$ & $25.24^{\mathrm{a}}$ & $8.75^{\mathrm{a}}$ & $53.80^{b}$ & $38.00^{\mathrm{b}}$ & $1600.72^{c}$ & $128.40^{\mathrm{a}}$ & $48.30^{c}$ \\
\hline
\end{tabular}

Means with the same alphabet along a column are not significantly different at $\mathrm{p}<0.05$ level of probability

Abbreviations: Sn - Stomata number, Nec- Number of epidermal cell, Si-Stomata index, Gcl- Guard cell length, Gcw- Guard cell width, Gca- Guard cell area,, Epidermal cell length, Epiderrmal cell width, $\mathrm{AB}-\mathrm{abaxial}$.

Table 4b: Mean Values of Important Quantitative Adaxial Epidermal Features of the Asplenium

\begin{tabular}{lccc}
\hline Species & $\mathrm{Nec}$ & $\mathrm{Ecl}(\boldsymbol{\mu} \mathrm{m})$ & $\mathrm{Ecw}(\mu \mathrm{m})$ \\
\hline A. nidus & $23.52^{\mathrm{b}}$ & $53.30^{\mathrm{a}}$ & $94.10^{\mathrm{b}}$ \\
A. scolopendrium & $18.40^{\mathrm{c}}$ & $52.00^{\mathrm{a}}$ & $108.40^{\mathrm{a}}$ \\
A. barterii & $29.92^{\mathrm{a}}$ & $44.70^{\mathrm{b}}$ & $93.20^{\mathrm{b}}$ \\
\hline
\end{tabular}

Means with the same alphabet along a column are not significantly different at $\mathrm{p}<0.05$ Abbreviations: Nec- Number of epidermal cell, Ecl- Epidermal cell length, Ecw- Epidermal cell width. 


\section{DISCUSSION}

The three species varied morphologically from simple fronds in both $A$. nidus and $A$. scolopendrium to pinnate fronds in $A$. barterii. $A$. nidus can be differentiated from $A$ scolopendrium by its glabrous fronds and more prominent sori. A. barterii is characterized by proliferating extended portion of rachis which has been observed in ferns such as Asplenium trichomanes, Asplenium gemmimiferum and Adiantum lunulatum (Crouch et al., 2011). The striking unique morphological character of the genus is the possession of elongated back to back sori on the vein. Length of sori is longest in $A$. scolopendrium while it is least in $A$. barterii. Large quantity of sori production may confer the advantage of increased rate of colonization on ferns since only few that lands on suitable substrate germinates. However, spore viability in ferns varies considerably among species (Eunice et al., 2010) and other factors such as light, temperature, storage period / condition and $\mathrm{pH}$.

The three species of Asplenium studied have common anatomical features which include hypostomatic fronds, and presence of druses on both adaxial and abaxial surfaces. Several workers have reported hypostomatic frond of Leptosporangiate ferns among which are Oloyede et al., (2011) and Bamigboye, (2018). Similarly, Lena et al (2018) found associated with hypostomatic ferns, guard cells densely packed with chloroplasts which differ from seed plants in light response mechanism. Nevertheless, common to both ferns and seed plants stomata is the ability to respond to photosynthetically active radiations.

The existence of more than only one type of stomata, anisocytic and helicocytic types, in $A$. nidus makes it stand out from the three species. $A$. barterii, observed to have the least frond size, has the highest stomata number on the abaxial surfaces but least guard cell area. Stomatal patterns in over 40 species of Polypodiaceae ferns from Himalaya when compared showed that the relevance of stomatal pattern, that is, stomata shape, size and type for taxonomic differentiation was at inter and intra specific levels
Venation patterns have been used extensively for fern classification into different genera (Fajuke et al., 2017). In this study, even though all the species have free veins, only the veins in $A$. nidus terminate at the frond margin. In addition, forking or branching of veins was at basal acrostical pinnae in $A$. barterii which makes it different from $A$. nidus where the basal veins are not forked.

Authors including Ogura (1972); Martinez and Vilte (2012) and Pitterman et al., (2015) have considered the taxonomic importance of fern vascular bundles. The presence of two distinct vascular bundles observed in the Asplenium species agree with a general feature of the family Aspleniaceae. More so, stipe character is reliable and stable in classifying ferns into various families (Resmietal., 2016).

\section{CONCLUSION}

From this study, it can be concluded that the three species vary in morphological characters such as, frond division, stipe colour and length. The possession of elongated sori and two vascular bundles are common characters which are important in delimiting the three investigated species of the genus Asplenium.

\section{REFERENCES}

Bassey, M.E. 1994. Taxonomic study of the family Adiantaceae from southeastern Nigeria. A PhD dissertation submitted to Department of Botany University of Port Harcourt, Nigeria, Pp. 1-159.

Bamigboye, R. A. 2018. Biosystematic study of the genus Pteris L. (Pteridaceae: Ferns) from southwestern Nigeria. A PhD dissertation submitted to Department of Botany, Obafemi Awolowo University, Ile-Ife, Nigeria, Pp.1-170.

Brownsey, P.J. and Perrie, L.R. 2018: Aspleniaceae. In: Breitwieser, I.: Wilton, A.D. Flora of New Zealand - Ferns and Lycophytes. Fascicle 18. Manaaki Whenua Press, $\begin{array}{lllllllllll}\mathrm{L} & \mathrm{i} & \mathrm{n} & \mathrm{c} & \mathrm{O} & \mathrm{l} & \mathrm{n} & \text {. }\end{array}$ http://dx.doi.org/10.7931/B1562D

Crouch, N.R., Klopper R.R., Burrows, J. E., 
Burrows, S.M. 2011. Ferns of Southern Africa. A comprehensive guide, 776pp.

Eunice, P., Debra, R.M., Marsa, M. and Aurea, M.R. 2011. Spore germination of Gneichnella pectinata (Willd) Ching (Polypodiopsida: Gleichniaceae) at different temperatures, level of light and $\mathrm{pH}$, Brazllian, Archives of Biology and Technology, 53(6):1590-1593.

Fajuke, A. A. 2014. Biosystematic studies of the genus Nephrolepis Swartz in southwestern Nigeria. A PhD Thesis submitted to Department of Botany Obafemi Awolowo University, Ile- Ife Pp.1-174.

Fajuke, A. A., Makinde. A. M., Oloyede, F.A. and Isa, M.O.2017.Pinna Growth and Development in Relation in Venation in Neprolepis Species. Notulae Scientia Biologicae, 9 (2.): 296-300

Franco, C. 1939. Relation between chromosome number and the stomata in Coffea. Botanical Gazette, 100: 817-820.

Lena, J. V, Scott, A. M., Michael, K., Jan, M. R., Tim, B., Rainer, H., M. Rob, G. and Roelfsema, M.J. 2018. Guard cells in fern stomata are connected by plasmodesmata, but control cytosolic $\mathrm{Ca}^{2+}$ levels autonomously New Phytologist 219: 2

Mannan, M.M., Maridas, M. and Victor, B. 2008. A Review on the potential uses of Ferns. Ethnobotanical Leaflets, 12: 281-285.

Martins, S. 2014. The Ferns Hendricks Park Eugene, Oregon Pp 24-25.

Martinez, G. O. and Vilte, I. 2012. The structure of petioles in Pteris (Pteridaceae) American Fern Journal, 102 (1): 1-10.

Oloyede, F.A. and Odu, E.A. 2011. Taxonomic evaluation of Homosporus Leptosporangiate Ferns: (Pteridophytes) in southwestern Nigeria. International
Journal of Current Research, 2 (2): 009017.

Oloyede, F. A., Akomolafe, F. G. and Oladipo, O.T. 2011. Comparative morphological and anatomical studies of Nephrolepis bisserrata (Swartz) Scott and Nephrolepis undulata (Afzelius ex Sw) J. Sm. in Nigeria. Journal of Science and Technology, 31(2):1-10.

Ogura, Y. 1972. Comparative anatomy of vegetative organs of the Pteridophytes. Gebruder Borntraeger. Berlin. Pp. 1-39.

Pitterman, J., Watkins, J. E., Car, K. L., Schuettpelz, E., Broadersen, C., Smith, A.R., and Baer, A. 2015. "The structure and function of xylem in Seed free vascular plant an evolutionary perspective" In Ecological and functional xylem Anatomy, ed. Uwe Hacke. Springer International.35pp.

Resmi, S., Thomas, V. P., and Sreenivas, V. K. 2016. Stipe anatomical studies on selected Pteridophytes of south India. Acta Botanica Hungarica, 58(1-2): 167-176.

SAS Institute 1997. System Analysis Software, version 9.1. SAS Institute.

Schneider, H., ～Russell, S.J., Cox, C. J., Bakker, F., Henderson, S., Rumsey, F. Barrett, J., Gibby, M. and Vogel, J. C. 2004. Chloroplast phylogeny of asplenioid ferns based on $r b c \mathrm{~L}$ and $t r n \mathrm{~L}-\mathrm{F}$ spacer sequences (Polypodiidae, Aspleniaceae) and its implications for biogeography. Systematic Botany, 29:260-274.

Yanfen, C., Jie, L.S.L. and Harald, S. 2013. Species diversity and reticulate evolution in the Asplenium normale complex (Aspleniaceae) in China and adjacent areas. Taxon, 62 (4): 673-687. 